\title{
Morphological Classification of Ganglion Cells in the Central Retina of Chicks
}

\author{
Yaoxing CHEN and Jumpei NAITO \\ Laboratory of Animal Morphology and Function, Division of Biofunctions Development, Graduate School of Bioagricultural Sciences, \\ Nagoya University, Chikusa-Ku, Nagoya 464-8601, Japan
}

(Received 9 December 1998/Accepted 9 January 1999)

ABSTRACT. Classification of retinal ganglion cells (RGCs) in the chick central retina was studied by retrograde labeling of carbocyanine dye (DiI) and intracellular filling with Lucifer Yellow. Ganglion cells were divided into 4 groups, Group Ic/Is, Group IIc/IIs, Group IIIs, Group IVc, according to sizes of somal area and dendritic field and dendritic branching pattern. Group I cells had small somal area and small dendritic field. They were further divided into 2 subgroups by complexity (subgroup Ic) and simplicity (subgroup Is) of the dendritic arborization. Group II cells had medium-sized soma and dendritic field. They were also divided into subgroup IIc and IIs by the same definitions as those of subgroup Ic and Is. Group IIIs had medium-sized soma, large and simple dendritic arborization. Group IVc in which all cells had large soma, showed large and complex dendritic arborization. Cell populations of each group were $51.8 \%$ (subgroup Ic), $21.1 \%$ (subgroup Is), 6.2\% (subgroup IIc), 14.6\% (subgroup IIs), 4.2\% (Group IIIs), and 2.1\% (Group IVc). Subgroup Ic cells, which were very similar to $\beta$-cells in the mammalian central area, represented about a half of the ganglion cell population. Cells in subgroup Is and IIs, which were not reported in the mammalian retina, were found in the chick central retina in relatively high population (35.7\%). Morphological features of chick RGCs in the central retina were considered in comparison with those of other vertebrates.-KEY wORDS: bird, cell type, ganglion cell, intracellular filling, retina.

J. Vet. Med Sci. 61(5): 537-542, 1999

Since the study of Cajal [6], it has been known that there is a morphological variety of retinal ganglion cells (RGCs) in vertebrates. Afterwards, RGCs have been attempted to classify morphologically in various vertebrates according to the differences of their morphological characteristics $[3,25$, 29]. On the other hand, it has been known since 1950s that there were some differences in physiological properties of RGCs [2, 27, 31], and they were classified into 3 groups, Y-, $\mathrm{X}$ - and W-cells, in the cat retina in 1970s [8, 13, 14, 40]. Boycott and Wässle [4] classified using Golgi impregnation techniques cat RGCs into 3 major types, which were named $\alpha-, \beta$-, and $\gamma$-cells. These 3 morphological types of ganglion cells, $\alpha-, \beta$-, and $\gamma$-cells corresponded to the physiologically defined groups of $\mathrm{Y}-, \mathrm{X}-$, and $\mathrm{W}$-cells, respectively $[4,15$, 38]. So far, RGCs have been divided into 3 major types in most mammals, but it is probable that they could be classified more precisely $[25,29,36]$.

In contrast to mammals, a variety of ganglion cell types was more abundant in the retina of cold-blooded animals. In the teleost, RGCs were divided into 3 to 11 types by Golgi staining [24] and retrograde labeling of horseradish peroxidase (HRP) [12, 19] or cobalt-lysine [9]. Amphibian RGCs were classified into 3 to 7 types with methods of silver impregnation [23], retrograde labeling by HRP [23, 41,43 ] or intracellular filling with fluorescent dye [39]. Kolb et al. [26] and Ammermüller and Kolb [1] divided turtle RGCs into 24 types (G1-G24) in Golgi and HRP studies.

On the other hand, only a few studies were performed to classify avian RGCs by retrograde HRP labeling [pigeons: 17; quails: 22]. Ikushima et al. [22] described 7 types of RGCs in quails. Thanos et al. [42], who investigated the regrowing ability of ganglion cells in the chick retina, labeled successfully dendritic arborization by DiI, and classified them into 8 groups. We attempted to classify chick RGCs in the ganglion cell layer (GCL) of the central retina. The central area of diurnal terrestrial birds such as chicks and quails is occupied by unimodal RGCs in somal size [7]. However, we hardly know whether or not the central area of the chick retina is really composed of a single type of RGCs like in primates [35].

\section{MATERIALS AND METHODS}

Intracellular filling with Lucifer Yellow (LY): Five chicks (White Leghorn) (posthatching day 8, P8) were used in this experiment. Under Nembutal anesthesia ( $45 \mu \mathrm{g} / \mathrm{g} \mathrm{BW}$ ), the lateral angle of the palpebra was cut laterally, and the conjunctiva was cut coronally along the eyeball. The eyeball was gently pulled out medially, and 3\% Fast blue (FB, Sigma) in distilled water was injected $(3 \mu l)$ into the optic nerve. After 5 days, chicks were perfused with $0.75 \%$ saline $\left(10 \mathrm{~m} l, 38^{\circ} \mathrm{C}\right)$, and $0.5 \%$ paraformaldehyde in $0.1 \mathrm{M}$ phosphate buffer $\left(20 \mathrm{ml}, \mathrm{pH} 7.4,4^{\circ} \mathrm{C}\right)$ through the heart using an injection needle (gage 22) under deep Nembutal anesthesia. After perfusion, the retina was carefully removed from the posterior hemisphere of the eyeball, and then stored in $4 \%$ paraformaldehyde in $0.1 \mathrm{M}$ phosphate buffer $\left(\mathrm{pH} 7.4,4^{\circ} \mathrm{C}\right.$ ) for $30 \mathrm{~min}$. Next, the retina was mounted on a gelatinized glass slide. Ganglion cells labeled by $\mathrm{FB}$ were randomly chosen one at a time in $2 \mathrm{mM} \mathrm{L-}$ ascorbic acid in $0.1 \mathrm{M}$ phosphate buffer $(\mathrm{pH} 7.4)$ and received an iontophoretical injection of 3\% LY (Polysciences) in distilled water for 30-120 sec under a fluorescence microscope (Olympus, excitation $365 \mathrm{~nm}$, absorption 420 $\mathrm{nm}$ ) (electrode negative: 5-10 nA). The retina was mounted 
by polyvinylalcohol 15000 (Fulka).

Retrograde labeling by DiI: Six chicks (P8) were perfused with the same method described above under deep Nembutal anesthesia. The eyeballs were dissected out from the orbit by cut close to the optic chiasm, and the lens and vitreous body were removed from the eyeball. Small crystals of DiI (1,1'-dioctadecyl-3, 3, 3', 3'-tetramethylindo-carbocyanine perchlorate; Molecular Probes, Eugene, OR) were placed on the caudal surface of the optic nerve stump under a dissection microscope. Then, the eyeball was immersed in $1 \%$ paraformaldehyde in $0.1 \mathrm{M}$ phosphate buffer $(\mathrm{pH} 7.4)$ for 4 weeks $\left(37^{\circ} \mathrm{C}\right)$. Ganglion cells labeled by DiI were examined under a fluorescence microscope (excitation 545 $\mathrm{nm}$, absorption $590 \mathrm{~nm}$ ).

Data analysis: Twenty-five cells labeled by LY and 23 cells labeled by DiI in the central retina of the ganglion cell layer (GCL) were morphologically analyzed. Microscopic images of labeled cells were photomicrographed using a $\times$ 40 objective (total magnification $\times 206$ ) on a $35 \mathrm{~mm}$ film (T-MAX 3200, Kodak). Images on the films were magnified at $\times 5.0$, and were traced onto the tracing paper. The image data were entered into an image analyzing system (Luzex III, NIRECO, Tokyo, Japan) via a CCD-TV camera and used as numerical data. The numerical data were statistically analyzed with the aid of computer software (Microsoft, Excel ver 8).

\section{RESULTS}

A total of 48 RGCs in the central retina (an area $2 \mathrm{~mm}$ around the highest density point) [7], which were completely labeled by retrograde labeling of DiI or by intracellular injection of Lucifer Yellow, were chosen and their somata and dendritic fields were measured. An advantage of labeling by intracellular injection was that target selection allowed investigation of particular cell classes at given eccentricities on the basis of sizes and retinal positions of somata and initial segments of primary dendrites. In contrast, an advantage of labeling by DiI was that a single crystal labeled all ganglion cell classes indiscriminately.

On the basis of morphological features of the soma and dendrite, RGCs in the GCL of the central retina were divided into 4 groups, that is, cells with small soma and small dendritic fields (Group I: $\times$ ), cells with medium-sized soma and dendritic field (Group II: $\boldsymbol{\Delta}$ ), and cells with large dendritic field (Group III: and Group IV: $\star$ ) (Fig. 1).

Group I: Thirty-five RGCs were defined as Group I cells. These cells were most frequently found in the GCL of the central retina $(72.9 \%$ of the total labeled cells). Group I cells had small somata (range: $34-138 \mu \mathrm{m}^{2}$, mean \pm S.D.: $76.9 \pm 25.7 \mu \mathrm{m}^{2}$ ) and were polygonal, round, or oval in shape. Dendritic fields of these RGCs were localized in a limited area (range: $1,790-34,000 \mu \mathrm{m}^{2}$, mean \pm S.D.: 15,900 $\pm 9,591 \mu \mathrm{m}^{2}$ ). Group I cells were divided into 2 subgroups by the branching pattern of dendrites. Subgroup Ic had 3 to 5 primary dendrites. They ramified highly frequently and irregularly to form a disorganized complex dendritic tree with numerous fine branches (71\% of Group I cells) (Figs. 2A, 3). Subgroup Is gave off 2 to 4 primary dendrites which poorly branched and formed the simple dendritic tree in the inner plexiform layer (IPL) (subgroup Is, Fig. 3). They occupied about $29 \%$ of Group I cells. Dendrites in $80 \%$ of Group I cells extended symmetrically to show round or oval dendritic fields. But in $20 \%$ of Group I cells, particularly in subgroup Is, dendrites showed asymmetrical dendritic pattern.

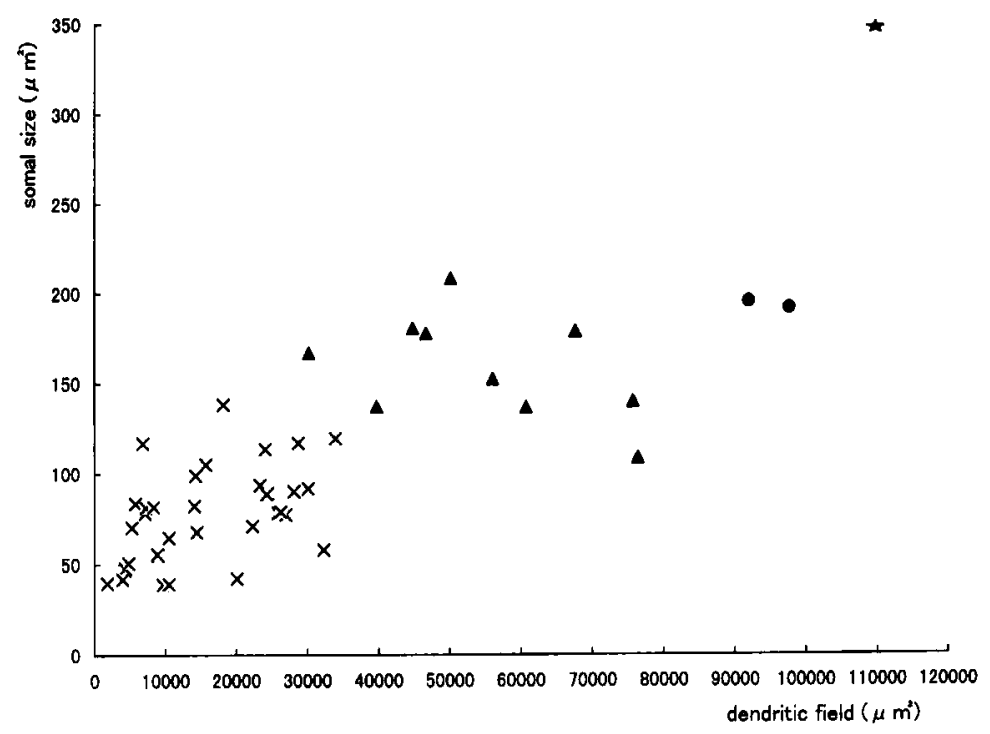

Fig. 1. Somal areas for cells of the 4 groups of RGCs represented as a function of their dendritic field areas. Forty-eight RGCs in the central retina from 11 chicks (P8) labeled by LY and DiI were plotted. Symbols represent as follows: Group I (X), Group II ( $\mathbf{\Delta})$, Group III ( $)$, and Group IV ( $\star$ ). 

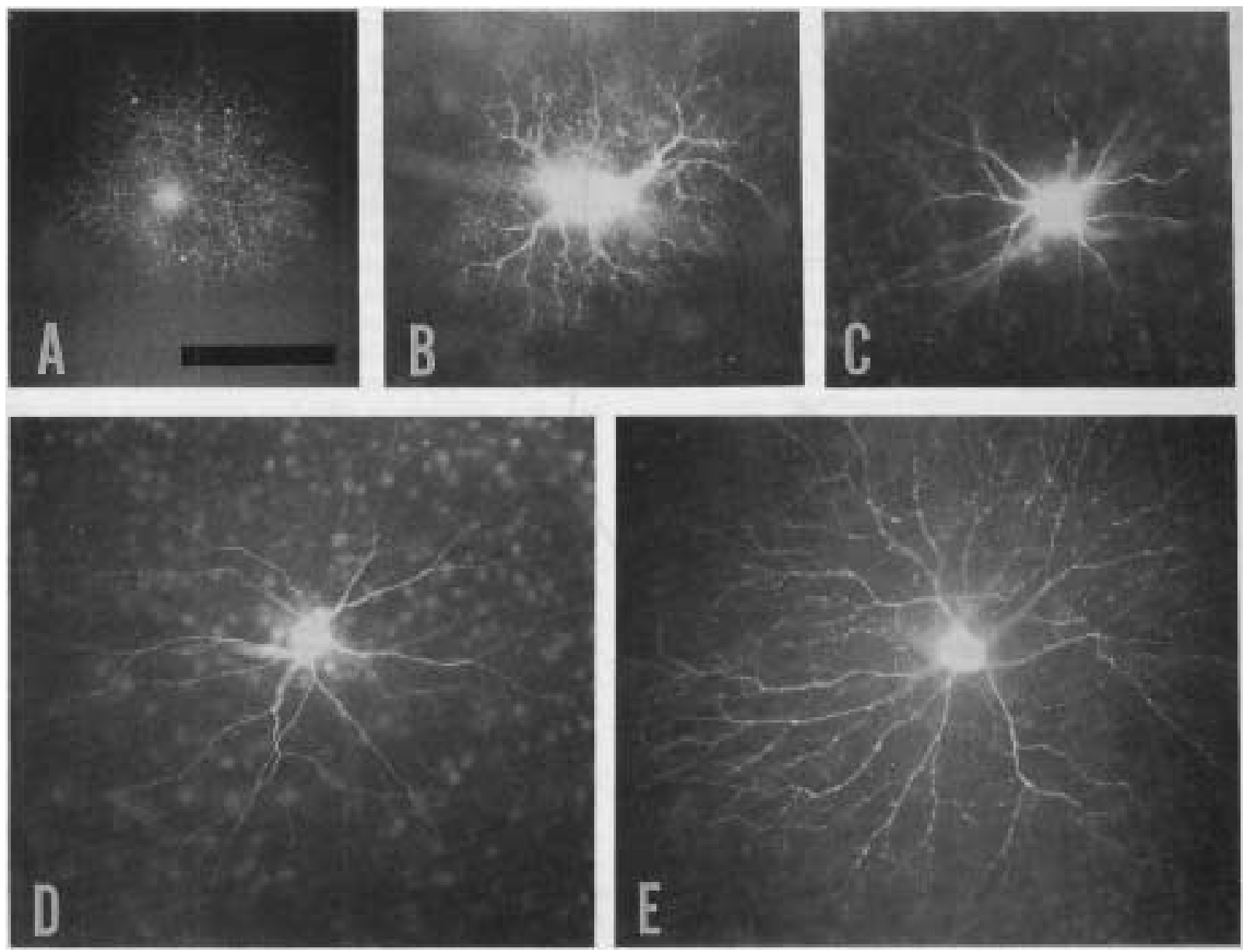

Fig. 2. Photomicrographs of RGCs in each subgroup labeled by retrograde axonal flow of DiI (A) and by intracellular filling with LY

(B-E). (A) subgroup Ic, (B) subgroup IIc, (C) subgroup IIs, (D) subgroup IIIs, (E) subgroup IVc. Bar=100 $\mu \mathrm{m}$

Group II: Ten labeled ganglion cells were classified as Group II cells. This group was the second largest group in chick RGCs $(20.8 \%$ of the total labeled cells). Cells in this group had small to medium-sized soma (range: 108-208 $\mu \mathrm{m}^{2}$, mean \pm S.D. : $158 \pm 27.6 \mu \mathrm{m}^{2}$ ) and were often polygonal or round in shape. Dendritic fields of these cells were also medium-sized (range: 30,300-76,500 $\mu \mathrm{m}^{2}$, mean \pm S.D.: $\left.54,900 \pm 14,609 \mu \mathrm{m}^{2}\right)$. Three to 5 primary dendrites emerged radially from the soma. The extent of their dendritic fields was symmetrical (90\% of Group II cells) with only a few asymmetrical ones (10\% of Group II cells). Group II cells were also divided into 2 subgroups based on branching pattern, subgroup IIs and IIc. Subgroup IIc cells had 4 to 5 thin primary dendrites, which showed a complex and dense dendritic arborization (Fig. 2B, 3). Subgroup IIs cells had 3 to 4 smooth primary dendrites which ramified into a few branches to show a simple and medium-sized dendritic tree (Fig. 2C, 3). Dendritic fields of these cells were medium-sized. Frequencies of subgroup IIs and subgroup IIc were $70 \%$ and $30 \%$, respectively.

Group III and IV: Cells in both groups were characterized by their large dendritic field. However, the numbers of these RGCs were only few in the central retina (Group III and IV: $4.2 \%$ and $2.1 \%$ of the total labeled cells). Group IIIs cells had medium-sized soma (range: 191-195 $\mu \mathrm{m}^{2}$, mean \pm S.D.: $193 \pm 1.8 \mu \mathrm{m}^{2}$ ), and their shapes were polygonal or round. Four to 5 long primary dendrites with small beads-like nodes branched infrequently to form large and simple dendritic tree (range: 92,200-97,800 $\mu \mathrm{m}^{2}$, mean \pm S.D.: 95,000 $\pm 2,154 \mu \mathrm{m}^{2}$ ) (Fig. 2D, 3). Group IVc cells were similar to those of Group IIIs cells in dendritic field size, but somal size and the dendritic pattern were clearly different from those of Group IIIs cells. Group IVc cells had large soma (mean \pm S.D.: $347 \mu \mathrm{m}^{2}$ ) and large and complex dendritic tree which were formed by many secondary and tertiary branches from 4 to 5 stout primary dendrites $\left(110,000 \mu \mathrm{m}^{2}\right)$ (Fig. 2E, 3). The dendritic tree was round or elliptic, and its extent was symmetrical.

Cells with varicosities in their dendrites: Numerous spherical dendritic swellings were observed in some cells in subgroup Is, subgroup IIc and IIs, Group IIIs, and Group IVc. These "varicosities" considerably varied in positions, sizes, and numbers. These swellings would be one criterion for classification of RGCs. 


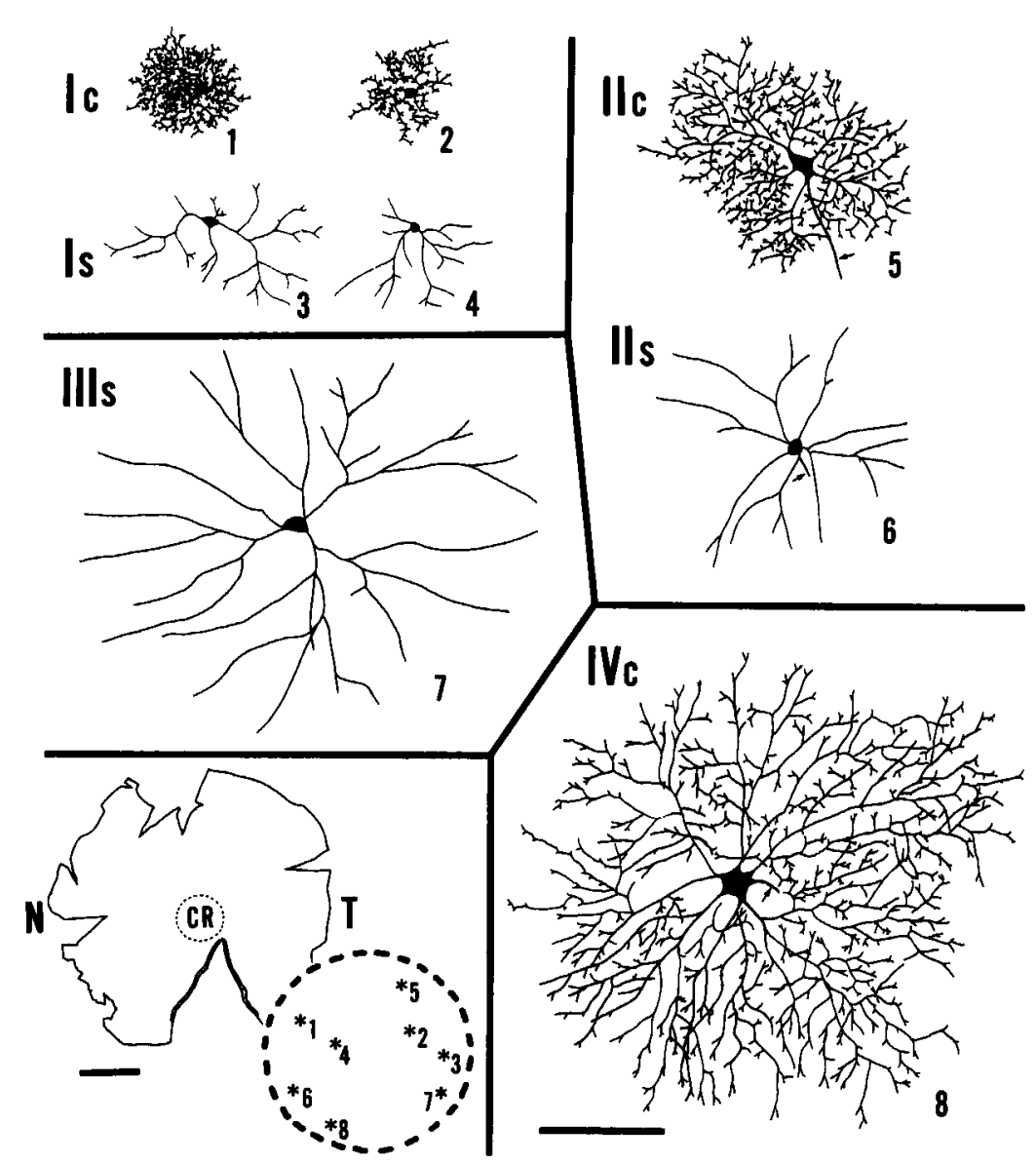

Fig. 3. Camera lucid drawings of RGCs classified into subgroups in the central retina (CR) shown in the retinal map at the lower left. Arabic numbers attached to each RGCs indicate the position in the central area by broken line's circle. Short and long bars in the bottom represent $5 \mathrm{~mm}$ for the retinal map and $100 \mu \mathrm{m}$ for RGCs, respectively.

\section{DISCUSSION}

Chick RGCs were divided into 11 idealistic types, which are created from the possible systematic combinations of somal sizes, dendritic field sizes, and dendritic branching patterns based on the data collected from the GCL in a whole retina [32]. Of these combinations, 6 types of RGCs were actually identified in the central retina: Group Is/Ic, Group IIs/IIc, Group IIIs, Group IVc.

Many studies reported that RGCs were composed of some type neurons in various vertebrates. However, some pieces of information on avian retinal ganglion cell types, particularly in the central retina, were given by some authors. Hayes [17] and Bravo and Pettigrew [5] divided pigeon and owl RGCs along the similar context to the mammalian classification using an HRP method. However, avian RGCs were divided into more classes by other authors. Ikushima et al. [22] described 7 ganglion cell types (2 types are displaced RGCs) in quails by HRP, and Thanos et al.
[42] classified them into 8 groups (one type is displaced RGCs) in chickens by DiI. Compared to these previous and the present results, even if there are some differences in fine nuance of criteria, they seem to be no significant variety derived from the differences in avian species. As shown in the present study, however, RGCs in the central retina were mostly composed of Group I cells and II cells, particularly subgroup Ic cells occupied about $50 \%$ of all labeled RGCs. According to Golgi [30] and HRP studies [18] in pigeons, RGCs in the central retina showed a single population composed of cells with small soma and small complex dendritic tree [18].

In cold-blooded animals, RGCs were morphologically classified more precisely with taking account of the stratification pattern of dendrites in the IPL by many authors (see Introduction). Collin [9] described that small cells were dominant in the central retina. In cold-blooded animals, characteristic types of RGCs with unipolar or bipolar dendritic fields are found frequently in the peripheral retina, but these types of neurons were not found in the 
central retina $[1,26]$. However, we found some RGCs with bipolar and asymmetrical dendrite trees in the central retina (subgroup Is, Fig. 3).

Retinal ganglion cells in various mammals were classified into 3 major types [primates: 16, 28; dogs and wolves: 33; foxes: 10 ; cats: $4,15,38$; ferrets: 44 ; rats: 21,34 ; mice: 11$]$. All 3 types (e.g. $\alpha, \beta, \gamma$ ) of RGCs were found in the central area where the densities of each type reached respective peaks. However, their populations were different with each other and also different between mammals and birds. For example, $\beta$ - and $\gamma$-cells occupied about $60 \%$ and $40 \%$ in the cat central area, respectively [20], and $\alpha$-cells were found only few percent $[20,44,45]$ in the central retina of cats and ferrets. The present study showed that subgroup Ic cells, which were similar to $\beta$-cells in mammals, indicated the lower population (51.8\% of all labeled central RGCs) than $\beta$-cell population in mammals. In contrast, the chick central retina contained a considerable number of such RGCs as had simple, and small to medium-sized dendritic tree (subgroup Is and IIs, 35.7\%) which could be hardly observed in the mammalian RGCs. Most dendritic arbors in the chick central retina extended radially, but some cells in subgroup Is showed systematic orientation. These data documented that chick RGCs are beside the current opinion with respect to the evolution of the central area, which involved in selections for systematic patterns of dendritic orientation and for cell types in the high-density region [37].

ACKNOWLEDGMENTS. The authors wish to thank Dr. K. Fukuta for encouragement through this study. This work was supported by Grants-in-Aid for JSPS Fellow (90001687) and in part by Grants-in-Aid for Scientific Research (C) (No. 09660317) from the Japanese Ministry of Education, Science, Sports and Culture.

\section{REFERENCES}

1. Ammermüller, J. and Kold, H. 1995. The organization of the turtle inner retina: I. ON- and OFF- center pathways. J. Comp. Neurol. 358: 1-34.

2. Bishop, G. H. and Clare, M. H. 1955. Organization and distribution of fibers in the optic tract of the cat. J. Comp. Neurol. 103: 269-304.

3. Boycott, B. B. and Dowling, J. E. 1969. Organization of the primate retina: light microscopy. Phil. Trans. Roy. Soc., B (Lond.) 255: 109-184.

4. Boycott, B. B. and Wässle, H. 1974. The morphological types of ganglion cells of the domestic cat's retina. J. Physiol. 240: 397-419.

5. Bravo, H. and Pettigrew, J. D. 1981. The distribution of neurons projecting from the retina and visual cortex to the thalamus and tectum opticum of the barn owl, Tyto alba, and the burrowing owl, Speotyto cunicularia. J. Comp. Neurol. 199: 419-441.

6. Cajal, R. S. 1892. The structure of the retina. (Transl. Thorpe, S. A. and Glickstein, M. 1972) Charles C. Thomas Publs., Illionis, USA.

7. Chen, Y. and Naito, J. 1999. A quantitative analysis of cells in the ganglion cell layer of the chick retina. Brain Behav.
Evol. 53: 75-86.

8. Cleland, B. G., Dubin, M. W. and Levick, W. R. 1971. Sustained and transient neurons in the cat's retina and lateral geniculate nucleus. J. Physiol. 217: 473-496.

9. Collin, S. 1989. Topography and morphology of retinal ganglion cells in the coral trout Plectropoma leopardus (Serranidae): a retrograde cobaltous-lysine study. J. Comp. Neurol. 281: 143-158.

10. Dann, J. F. and Buhl, E. H. 1990. Morphology of retinal ganglion cells in the flying fox (Pteropus scapulatus): a Lucifer yellow investigation. J. Comp. Neurol. 301: 401-416.

11. Doi, M., Uji, Y. and Yamamura, H. 1995. Morphological classification of retinal ganglion cells in mice. J. Comp. Neurol. 356: 368-386.

12. Dunn-Meynell, A. A. and Sharma, S. C. 1986. The visual system of the channel catfish (Ictalurus punctatus). I. Retinal ganglion cell morphology. J. Comp. Neurol. 247: 32-55.

13. Enroth-Cugell, C. and Robson, J. C. 1966. The contrast sensitivity of retinal ganglion cells of the cat. J. Physiol. 187: 517-552.

14. Fukada, Y. 1971. Receptive field organization of cat optic nerve fibers with special reference to conduction velocity. Vision Res. 11: 209-226.

15. Fukuda, Y., Hsiao, C.-H., Watanabe, M. and Ito, H. 1984. Morphological correlates of physiologically identified Y-, X-, and W-cells in cat retina. J. Neurophysiol. 52: 999-1013.

16. Ghosh, K. K., Goodchild, A. K., Sefton, A. E. and Martin, P. R. 1996. Morphology of retinal ganglion cells in a New World monkey, the marmoset Callithrix jacchus. J. Comp. Neurol. 366: 76-92.

17. Hayes, B. P. 1982. The structural organization of the pigeon retina. Prog. Ret. Res. 1: 197-226.

18. Hayes, B. P. and Holden, A. L. 1980. Size classes of ganglion cells in the central yellow field of the pigeon retina. Exp. Brain Res. 39: 269-275.

19. Hitchcock, P. F. and Easter, S. S. Jr. 1986. Retinal ganglion cells in goldfish: a qualitative classification into four morphological types, and a quantitative study of the development of one of them. J. Neurosci. 6: 1037-1050.

20. Hughes, A. 1981. Population magnitudes and distribution of the major modal classes of cat retinal ganglion cells as estimated from HRP filling and a systematic survey of the soma diameter spectra for classical neurons. J. Comp. Neurol. 197: 303-309.

21. Huxlin, K. R. and Goodchild, A. K. 1997. Retinal ganglion cells in the Albino rat: revised morphological classification. J. Comp. Neurol. 385: 309-323.

22. Ikushima, M., Watanabe, M. and Ito, H. 1986. Distribution and morphology of retinal ganglion cells in the Japanese quail. Brain Res. 376: 320-334.

23. Kock, J.-H., Mecke, E., Orlov, O. Y., Reuter, T., Väisänen, R. A. and Wallgren, J. E. C. 1989. Ganglion cells in the frog retina: discriminate analysis of histological classes. Vision Res. 29: 1-18.

24. Kock, J.-H. and Reuter, T. 1978. Retinal ganglion cells in the crucian carp (Carassius carassius). II. Overlap, shape and tangential orientation of dendritic trees. J. Comp. Neurol. 179: 549-568.

25. Kolb, H., Nelson, R. and Mariani, A. 1981. Amacrine cells, bipolar cells and ganglion cells of the cat retina: a Golgi study. Vision Res. 21: 1081-1114.

26. Kolb, H., Perlman, I. and Normann, R. A. 1988. Neural organization of the retina of the turtle Mauremys caspica: a light 
microscope and Golgi study. Vis. Neurosci. 1: 47-72.

27. Kuffler, S. W. 1953. Discharge patterns and functional organization of mammalian retina. J. Neurophysiol. 16: 37-68.

28. Leventhal, A.G., Rodieck, R.W. and Dreher, B. 1981. Retinal ganglion cell classes in the old world monkey: morphology and central projections. Science 213: 1139-1142.

29. Linberg, K. A., Suemune, S. and Fisher, S. K. 1996. Retinal neurons of the california ground squirrel, Spermophilus beecheyi: a Golgi study. J. Comp. Neurol. 365: 173-216.

30. Lockhart, M. 1979. Quantitative morphological investigation of retinal cells in the pigeon: a Golgi light microscopic study. pp. 371-394. In: Neural Mechanisms of Behaviour in the Pigeon (Granda, A. M. and Maxwell, J. H. eds.), Plenum Press, New York.

31. Maturana, H. R., Lettvin, J. Y., McCulloch, W. S. and Pitts, W. H. 1960. Anatomy and physiology of vision in the flog. $J$. Gen. Physiol. 43 (Suppl. 2): 129-175.

32. Naito, J., Chen, Y. and Fujiwara, A. 1998. Morphological analysis of ganglion cells in the ganglion cell layer (GCL) in chick retina. Inves. Ophthal. Vis. Sci. 39: 563.

33. Peichl, L. 1992. Morphological types of ganglion cells in the dog and wolf retina. J. Comp. Neurol. 324: 590-602.

34. Perry, V. H. 1979. The ganglion cell layer of the retina of the rat: a Golgi study. Proc. R. Soc. Lond., B 204: 363-375.

35. Polyak, S. L. 1941. The retina. Univ. of Chicago Press, Chicago.

36. $\mathrm{Pu}$, M., Berson, D. M. and Pan, T. 1994. Structure and function of retinal ganglion cells innervating the cat's geniculate using an in vitro study. J. Neurosci. 14: 4338-4358.
37. Rowe, M. H. and Dreher, B. 1982. Functional morphology of beta cells in the area centralis of the cat's retina: a model for the evolution of central retinal specialization. Brain Behav. Evol. 21: 1-23.

38. Saito, H. 1983. Morphology and physiologically identified $\mathrm{X}$-, Y- and W-type retinal ganglion cells of the cat. J. Comp. Neurol. 221: 279-288.

39. Sakaguchi, D. S., Murphey, R. K., Hunt, R. K. and Tompkins, R. 1984. The development of retinal ganglion cells in a tetraploid strain of Xenopus laevis: a morphological study utilizing intracellular dye injection. J. Comp. Neurol. 224:231-251.

40. Stone, J. and Hoffmann, K. P. 1972. Very slow-conducting ganglion cells in the cat's retina: a major new functional type. Brain Res. 43: 610-616.

41. Straznicky, C. and Straznicky, I. T. 1988. Morphological classification of retinal ganglion cells in adult Xenopus laevis. Anat. Embryol. 178: 143-153.

42. Thanos, S., Vanselow, J. and Mey, J. 1992. Ganglion cells in the juvenile chick retina and their ability to regenerate axons in vitro. Exp. Eye Res. 54:377-391.

43. Toris, C. B., Eiesland, J. L. and Miller, R. F. 1995. Morphology of ganglion cells in the neotenous tiger salamander retina. J. Comp. Neurol. 352: 535-559.

44. Vitek, D. J., Schall, J. D. and Leventhal, A. G. 1985. Morphology, central projections, and dendritic field orientation of retinal ganglion cells in the ferret. J. Comp. Neurol. 241: $1-11$.

45. Wässle, H., Levick, W. R. and Cleland, B. G. 1975. The distribution of the alpha type of ganglion cells in the cat's retina. J. Comp. Neurol. 159: 419-438. 